๑) Open Access Full Text Article

ERRATUM

\title{
Anti-CD30-targeted gold nanoparticles for photothermal therapy of L-428 Hodgkin's cell [Erratum]
}

Qu X, Yao C, Wang J, Li Z, Zhang Z. International Journal of Nanomedicine. 2012;7:6095-6103.

The caption for Figure 4 was incorrect in the published paper. The correct Figure 4 caption is as follows:

Figure 4 Photothermal treatments of L-428 cells with goldBerH2 conjugates. (A) Without laser irradiation; (B) with $532 \mathrm{~nm}$ laser irradiation with $50 \mathrm{~mW}, 5$ pulses.

International Journal of Nanomedicine

\section{Publish your work in this journal}

The International Journal of Nanomedicine is an international, peerreviewed journal focusing on the application of nanotechnology in diagnostics, therapeutics, and drug delivery systems throughou the biomedical field. This journal is indexed on PubMed Central, MedLine, CAS, SciSearch ${ }^{\circledR}$, Current Contents ${ }^{\circledR} /$ Clinical Medicine,

Journal Citation Reports/Science Edition, EMBase, Scopus and the Elsevier Bibliographic databases. The manuscript management system is completely online and includes a very quick and fair peer-review system, which is all easy to use. Visit http://www.dovepress.com/ testimonials.php to read real quotes from published authors.

submit your manuscript | www.dovepress.com

Dovepress

http://dx.doi.org/| 0.2147/IJN.S439|| 